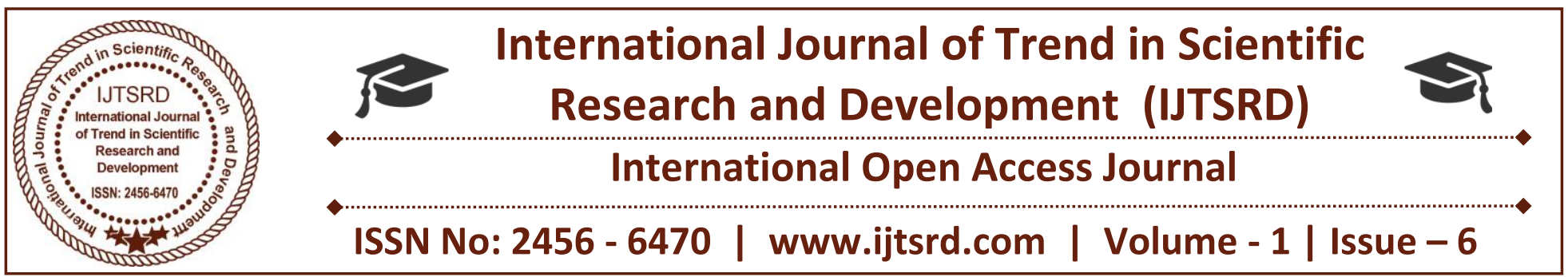

\title{
Closing Indigenous Manpower Gap in Oil and Gas Industry in Niger Delta for Sustainable Peace through Local Content Act
}

\author{
Dr. Maduawuchi Elem \\ Social Studies Department, \\ Ignatius Ajuru University of Education, \\ Rumuolumeni, Port Harcourt, Nigeria
}

\author{
Dr. Dokubo, Isaac Nwojiewho \\ Department of Vocational and Technology \\ Education, Rivers State University, \\ Nkpolu, Port Harcourt, Nigeria
}

\section{ABSTRACT}

This paper examines how the indigenous manpower development objective in the Nigeria Local Content (LCA) Act can bring about sustainable industrial peace in the Nigerian petroleum sector and the Niger Delta. The paper discovered that NLCAct is driven by the vital role oil sector plays in the Nigerian economy; the huge amount in foreign currency spent in servicing the industry vis-a-vis the small revenue earned due to poor manpower and its induced conflict among others on the industry. Secondly, that indigenous manpower objective in NLC, Act if extended to the Niger Delta region will serve as a valid therapy to bring about peace both to the industry and Niger Delta region as the intent of the former is one of the cardinal issues in Niger delta crisis. Based on these, the work recommends that there should be a data base of available skills among other options by the state governments in the region. These governments will then liaise with companies in the industry and the communities for proper job placement and that the government should go unto aggressive skill acquisition programme for the youth.

Keywords: Oil and gas, Indigenous manpower gap, Industrial peace, Local content Act, technical skills

\section{INTRODUCTION}

Petroleum industry has been the driving force of Nigeria economic development and will remain so in future. In the global crude oil market, Nigeria occupies seventh position with an estimated crude oil reserve of about 40 billion barrels. According to Ugwushi, Chris and Kamdi (2009) an estimated \$8 billion is spent annually in fabrication, engineering procurement, Construction, Front End Engineering Design; Conceptual Design and Seismic Studies in the oil sector alone. Stressing this, Business day (2008) in Ugwuchi, Chris and Kamdi (2009) project the figure to hit $\$ 15$ billion within the next few years. The implication of these is that the industry has become not just the nucleus of Nigeria economy but alive wire in employment generation.

Of these sums spent and projected in servicing the industry, only a very insignificant amount is invested in developing indigenous manpower. The equipment and all the technology needed in the Engineering and production are imported. These therefore remove Nigeria far away from maximizing the values expected in the industry. Stressing this, James, Claudius and Taiwo (2009) reveal that the industry is dominated by foreign entrepreneurs and that the preponderance of expatriate workers can result to paucity of skills development, capacity building and utilization for the indigenous workforce. Over the years, lack of indigenous manpower has been the core reason why foreign firms are unable to employ Nigerians especially the indigenes of oil bearing 
communities in the Niger Delta. The persistence of this is one of the reasons why the Niger Delta region is in crisis.

According to Aneke (2002); Ariweriokuma (2009) and Ihua (2010), the lack of local content is the chief cause of why oil-fields services contracts are given to foreign firms as local industries cannot enjoy competitive advantage over foreign firms in providing same services in the industry. In this sense, indigenous manpower is a propelling force for national growth as well as socio-economic and political development. It stands as the main capital stock of any nation, the basic resource and an indispensable means of converting other resources to satisfy man's needs. Furthermore, available stock of indigenous manpower determines whether nations can achieve full industrialization objectives.

The absence of indigenous manpower for the industry not only adversely affects Nigerians in general, it also provides the leeway for foreign firms who are dominating the sector to fill the available positions with foreign experts from their home countries; yet unemployment is one of the core elements in the Niger Delta crisis. In addition, it has become a veritable instrument to undermine series of memoranda of understanding and agreements with the host communities.

Today, Niger Delta Avengers (NDA), the militant group spearheading the protest against both federal government and the oil companies have destroyed oil production facilities in such a manner that Nigeria oil production has dropped drastically. The impact of this is reflected in the current Nigeria's economic recession. Again their activities have become a serious threat to Nigeria's corporate existence (Musapha, 2016). Commenting on the seriousness of NDA's constant attack on oil facilities in Nigeria recessed economy, John Mahama, Ghana president claims that NDA's activities did not only crippled Nigeria's oil revenue, but has also affected power supply in Ghana(Venturesatrica.com/how-theactivities Niger Delta Avenger are affecting Ghana). Commenting on this, Ibe Kachikwu, Nigeria's former minister of Petroleum Resources and Group Managing Director of the Nigeria National Petroleum Company in Pulse News Agency, June 6, 2016 claims that Nigeria's total output has dropped below 1.3 million barrel per day (bpd) from 2.2 million bpd at the start of the 2016.
Stressing further, Pulse News Agency claims that NDA activities forced oil price to $\$ 51$ per barrel from $\$ 40$ and that NDA's string of attacks has brought Nigeria's production to the lowest in 20 years. These developments predicates Nigeria Local Content (NLC) Act as an instrument to domesticate and enhance capacity building in the oil Nigerian and gas industry and to resolve other social problems in the industry that can hinder efficiency in the sector. This is doubly significant given the fact that efficiency in the industry is itself contingent upon a resolution of the social problems and the contradictions in the sector.

Today the activities of NDA protesting noninvolvement of host community in oil industry have virtually crippled the oil sector and have reduced Nigeria's crude oil out-put. On 10th February 2016 NDA blow-up Bonny Soku Gas pipeline which supplies gas to Nigeria Liquefy Natural Gas (NLNG) Plant as well as the Gbaran Independent Power Plant. On 14th February, NDA destroyed the Trans Forcados Pipeline (TFP) which carries water, associated gas and 400,000 barrels of oil per day from Western Delta field. On 4th of May, 2016 NDA struck and blow up Chevron valve platform in Warri. Again, on 26th of May, 2016 chevron well which feeds Warri and Kaduna refineries with gas in Abiteye was struck. This informed why Federal Government Launched Operation Crocodile Smile, a military operation designed to flush out NDA.

All these have reduced Nigeria's Oil production from 2.2 bpd (N279 representing \$14 billion bpd loss). These which have cripple Nigeria oil exports, reduced the supply of gas to local power plants thereby hobbling Nigeria's power grid. Presently Electricity generation has declined from its 1,010 megawatts in August 2015 to 800 megawatts in May 2016. These have seriously affected Nigeria gross domestic production in service delivery as oil operation were temporarily suspended (Freedom, 2016).

These backgrounds informed the need for NLC Act which was signed into law in $2 / 4 / 2010$. The overall objectives of this Act include expansion of the upstream and downstream sectors of Nigeria oil and gas investment. In addition, it is meant to foster technological transfer and increase in production capacity among others. By this, foreign oil firms operating in Nigeria must increase their Nigerian Content to meet the new rule as well as give Nigerians 
first priority in their employment and contracts. In the light of these, this paper attempts to examine how NLC Act, beyond developing indigenous manpower objective in petroleum sector, can be extended to bring about sustainable peace in the sector and the Niger Delta region; a region ridden with oil induced crisis perpetuated by both Nigeria government and the oil companies operating in the region.

\section{LOCAL CONTENT ACT: MEANING AND GENERAL OVERVIEW}

NLC Act, also christened Nigeria Local Content Policy, is that quantum of composite value added or created in the Nigerian economy through the utilization of Nigerian human and material resources for the provision of goods and services to the petroleum industry (Nigerian Oil and Gas Development Law, 2010) in Gbegi and Adebisi (2013). The Act has 107 sections, all of these apply to operators, contractors and other entities in the petroleum sector. The primary intent is to nationalize, or Nigerianise the oil and gas industry. Put the other way, it is a policy frame work designed within the context of growth of Nigerian entrepreneurship and the domestication of assets to the full in other to achieve real development in the petroleum industry. In sum, it is purely a value creation policy, aimed at the development of indigenous capacity and the utilization of Nigerian human, materials and other resources (Adeoye and Adefulu 2013).

Reflecting on this, Obuaya (2015) succinctly captures it as a set of deliberate orientation and action to build domestic capacity relevant for a service and product delivery comparable within that industry and an opportunity to locally build a sustainable culture of service quality and capabilities exceeding customers' expectations and comparable to international standards through key local personnel and management. The idea of deliberate orientation, capacity building, sustainable capacity, product deliverability systems and comparability as used by Obuaya (2015) strongly reduce local content as a policy with community content.

\section{INDIGENOUS MANPOWER DEVELOPMENT COMPONENTS}

In respect to manpower development, the following sections were enacted: Section 41 empowered the minister of Petroleum to set targets for full utilization and growth of indigenous companies in exploration seismic data processing; engineering design, reservoir studies; manufacturing and abrication of quipment, and other facilities plus the provision of other support services for Nigerians doing business in the oil and gas industry.

The promotion of human capital is contained in section 28-35 of the Act. Section 28 subsection (1) makes it mandatory for Nigerians to be given first choice in employment and training in any project in the industry. In this respect, the Act requires that Nigerian content plan be submitted by all contractors in the sector. Such plan should include employment and training plan for Nigerians.

Section 30 and 31 equally make it compulsory for all contractors in the industry to provide training facility to Nigerians where such persons lack the required skills for employment. Furthermore, the Act requires all operators in the industry to make provision for a succession plan for Nigerians in such circumstance to undergo internship training under an expatriate staff for four (4) years.

To enable trained Nigerians get the opportunity for employment after training, section 33 makes it mandatory for all expatriates to apply first to a board which will accept or reject such expatriate. This board has the power to place a minimum percentage of Nigerian workers. More specifically, the Act requires all companies in the industry to employ only Nigerian staff. It specifies 5 per cent to expatriate manager's position in respect to each project. Section 37, 38 and 39 address Research and Developments issues. In this sense, the Act requires all operators to submit education promotion, research and development plans to the board. Section 43 addresses transfer of technology. The operators are required to provide a programme for the purpose of promoting the transfer of technology into Nigeria in the sector. To effectively achieve this, the Act in section 53 mandates all operators in the industry to carry out all its fabrications and welding works in Nigeria.

Similarly, Section 25 makes it compulsory for all firms in the industry to establish project offices in the catchment areas, the host communities. Such office(s) must be established before the take -off of the project. It is believed that this section possesses the capability to absorb available local skills. This way, rural development, one of the core demands of the Niger 
Delta is addressed. For effective performance of the above the Act establishes Nigeria content Development and Monitoring Board, which is charged with the responsibility of overseeing the full implementation of the Act.

\section{THE NIGER DELTA}

The region has two meanings: Political and Traditional meaning. The first meaning is derived from the government definition to mean all oil producing communities. This informed the inclusion of Imo, Abia and Ondo in the Niger Delta Development Commission (NDDC). Traditional Niger Delta are the South-South States of Bayelsa, Rivers, Akwa-Ibom, Cross River State, Delta and Edo States. This constitutes the core Niger Delta and is the concern of this study. The region is characterized by wetland and water bodies and rivers. It sits on the bright of Biafra side of the Gulf of Guinea, directly on the Atlantic Ocean. It is rich in natural resources especially oil and gas which constitute over 70 percent of Nigeria foreign exchange earnings.

The region has an estimated population of about 30 million people covering about 40 ethnic nationalities speaking about 250 dialects and languages (Wikipedia, 2010) in (Ofili, 2012). Its land mass is about $70,000 \mathrm{~km} 2(27,000 \mathrm{~s}$ of miles). The region occupies Nigeria's last line of defense, the Atlantic Ocean. It houses the largest mangrove forest in the world and extensive forest water swamp and tropical rainforest. Given these characteristics, the terrain is quite difficult and tricky.

\section{NIGERIA LOCAL CONTENT ACT AND INDIGENOUS MANPOWER DEVELOPMENT FOR SUSTAINABLE INDUSTRIAL PEACE IN OIL INDUSTRY IN NIGER DELTA REGION}

The overall objective of the Act of indigenizing the oil and gas sector is a novel one. If the contents are followed strictly it can put Nigeria properly in the industrialize world, thereby reducing the uncertainty in the economy and the Niger Delta region .Firstly it can lead to endogenous growth as investments in human capital and knowledge are critical for economic growth. The beauty of endogenous growth is that it has a spillover effect capable of bringing about economic development. The Asian Tigers, China and Indians remain common models in this regard. They used this formula against sophisticated advice from World Bank and the Western world to meet most of their industrial needs. Today, they are economic super powers, exporting their technologies to other economies (Asuru and Amadi, 2016).

In this sense, LCA will reduce vulnerability of the oil industry and the economy at large. This is possible given the central role oil and gas plays in Nigeria development and how much is lost on importation of products, skills and tools for the industry. The absence of this is responsible for frequent short-downs, low production resulting to shortage of petroleum products to meet local need. It is also responsible for the corruption and the current sleaze in the industry, including the; fuel subsidy scam which cost Nigeria about 1.5 trillion Naira annually (Nwachukwu, 2016) in (Asuru and Amadi, 2016)

In the regime of growing industrialization and value chain, job creation will increase, thus employment generation which is one core issue in the Niger Delta crisis will be addressed. In this respect an application of the spirit of the Act to the host communities can become a vent to reduce agitation pressure from the host community even from the staff in the sector. Such gesture will no doubt, absorb most of the technicians trained in the amnesty programme.

When this is contrast against paragraph 37 of the Act which demands that 75 per cent of the managerial, professional and supervisory grade in Lease business be Nigerians and that 60 per cent minimum requirement of total management and all skills, semi-skilled workers who must be Nigerians, we will have a deepened understanding of how NLC Act can facilitate sustainable peace in the industry and the Niger Delta.

Sections 30 and 31 are of great importance in this respect. These section makes it obligatory for all operators, in the industry to engage Nigerians for training where such persons cannot be employed due to lack of relevant skills. These sections further require such firms to provide a succession programme where Nigerians will understudy expatriates for few years. This process will accommodate the interest of some ex-militants even new militants who are still creating problems because they are not accommodated in the amnesty programme. Again, restricting the usual influx of expatriates to 5 percent will create greater demand for indigenous labour.

This way, empowerment will be achieved and the issue marginalization of the host communities in the ownership of their God-given resources will be 
reduced to a manageable level. When this is juxtaposed with section 25 which requires that operators in oil industry open offices in their catchment areas, we will be able to appreciate better how restive nerves would be calmed, thus making possible enduring peace. According to this section, the offices must be established before the works on the project starts. This section possess the capacity to utilize the available local skills, thus rural development, another core demand of the Niger Delta is addressed. This way high poverty level which drive nefarious activities like oil theft and illegal oil bunkering which deepened environmental crisis in the region will reduce.

\section{CONCLUSION}

Nigeria NLC Act is not just economic nationalism, but an effort to utilize/development indigenous manpower to maximize optimally the revenue that accrue to the nation from the oil and gas sector. It is clear that the NLC Act is a therapy to bring about sustainable industrial peace in Nigeria oil sector and by extension the Niger Delta region where oil exploration activities take place. This is because the contending issues driving the NLC Act constitute the core issues in Niger Delta crisis; a crisis that has threatened Nigeria national security and socioeconomic life. The NLC Policy if properly applied in Niger Delta region, will address the problems of poverty and empowerment, thus the problem of ownership of resources will be reduced. In this sense, NLC Act will help to integrate and mobilize especially the communities, the militant youths from the region as well as build strong partnership between the oil companies, the government and the host communities from the region. Such effort will help to achieve NLC manpower objective; reduce environmental crisis associated with their activities; douse conflict in the region; increase wealth and make petroleum products more available. This way most persons will be productively engaged, peace will return to the industry and the region in particular.

\section{RECOMMENDATIONS}

For the expected advantages to be achieved, it is expedient for;

1) A functional channel of communication to be established among the government, the oil companies and the host communities. This should be handled by the various States' Ministry of Employment who will have a data base of available skills in the host communities and data base of new and old oil operators in the industry.

2) The primary role of the ministry should be to interface between the company and the communities. Through such interface, proper job placement and bargain will be easy.

3) It is equally necessary for government, especially state governments in the region to embark on aggressive technical and vocation education training for youths. This will require that more technical schools be built.

4) Establishment of Petroleum universities as well as proper funding of Petroleum Training Institute.

5) There should be formalization and legalization of modular/ prohibited indigenous refineries in the Niger Delta through proper policy frame, legislation and adequate training programmes.

6) Finally soft loans should be of great essence so that people who are not able to get formal jobs can use the same means to provide other services like contract supply to the oil companies.

\section{REFERENCES}

1) Abegi, D.O \& Adebisi, J.F. (2013). Managing local content policies in the extractive industries. Research Journal of finance and Accounting 4(7) pp 90-98. Retrieved 27th September, 2014.

2) Adage, A.O \& Adefullu's Chambers (2010). Nigeria/Local Content Policy. Accessed from adujinrinadefulu.com/documents/Nigeria 90/10/2016.

3) Aneke, P. (2002). The role of major operators in the development of local content in the Nigerian oil and gas industry. A paper delivered during a national seminar on dynamics of equipment leasing and contract financing for local contradictors in oil and gas sector Port Harcourt, Nigeria.

4) Ariyo, D. (1998). Small firms are the backbone of the Nigeria economy. Africa Economic Analysis, Africa Business Information Serces, Bridgnnth.

5) Ariweriokuma, S. (2009). The political economy of oil and gas in Africa:The case of Nigeria. New York Rout ledge.

6) Asuru,C. and Amadi, S.(2016). Technological capability as a critical factor in a Nigerian development : the case of indigenous refineries in the Niger Delta. International journal of innovative research in education, Technology and Social Strategies.pp144-153 
7) Freedom, C.O. (2016). The resurgence of militancy in Nigeria's oil-rich Niger Delta and the dangers of militarization access at access study. aljazeera.net/en/reports/2016 11 September 2016.

8) Ihua, U. B. (2005). Small and Medium-Scale Enterprises: Catalysts of Economic Growth of the Nation. Unpublished MBA Dissertation. University of Ado-Ekiti.

9) Mac Pepple, H. (2002). An overview of operation of local contractors in Nigerian oil and gas industry: key issues. A paper delivered at a technical workshop on local content in Port, Harcourt, Nigeria.

10) Momodu, K.M. \& Cornelius, B.N. (2012). The Nigerian Petroleum Industry Bill 2012: Some observations. Petroleum Technology Development Journal 2(2) PP 101-107.

11) Mustapha, A. (2016). Niger Delta Avengers Pose serious threat to Nigeria's corporate existence. accessed-ventguesatrica.com/how-the activities of Niger Delta has affected Ghana.

12) Ndulse, E. (2015). The media in the implementation of Nigeria oil and gas industry content Act, 2010. A Paper presented to member of the Nigeria Union of Journalist, Akwa-Ibom State Council on August, 26/2016.

13) Obuaya, T. (2015). Local content implementation in Nigerian: a road map. paper presented at the Nigeria oil and gas conference, Abuja, Nigeria.

14) Pulse News Agency (2016). Niger Delta Avengers' Militant activities force oil price to $\$ 51$ per barrel.

15) Ugwuchi, B.I; Christ, A \& Kamdi, N. (2009). Nigerian Local content policy in the oil and gas industry: Implications for small and medium-size. Proceedings of the 10th annual conference on Repositioning African Business and Development in the 21st century. Vanguard Newspaper July 19, 2016. 